\title{
Epidemiological studies of diabetes mellitus in Denmark: 5. Mortality and causes of death among insulin-treated diabetic patients
}

\author{
A. Green ${ }^{1}$ and P. Hougaard ${ }^{2}$ \\ ${ }^{1}$ University Institute of Clinical Genetics, Odense, and ${ }^{2}$ Statistical Research Unit, Danish Medical and Social Science Research Councils, \\ Copenhagen, Denmark
}

\begin{abstract}
Summary. A 7-year follow-up study is reported on the prevalent population of all insulin-treated diabetic patients $(n=1499)$ as of 1 July 1973 in the Funen County, Denmark. The analysis of mortality was based on data from 395 dead and the remaining 1104 living patients. Males had a significantly higher mortality than females and a lower age at onset was associated with a significantly higher mortality. An analysis of the causes of death revealed a higher than expected number of deaths in all categories studied, although the excess mortality was highest for diabetes mellitus itself and cardiovascular diseases. Diabetes mellitus was not notified on 15\%
\end{abstract}

of the death certificates, and this under-reporting varied according to duration of the disease and place of death. It is concluded that studies based solely on death certificates will underestimate the mortality of diabetes mellitus, and that further longitudinal studies of well-defined, population-based patient groups are needed to evaluate the determinants of mortality in diabetes.

Key words: Insulin-treated diabetes, mortality, regression analysis, death certificates, causes of death.
Irrespective of clinical type and treatment, diabetes mellitus is associated with a considerable excess mortality which has been shown to be due primarily to cardiovascular diseases $[1,2]$. In spite of the universal agreement on this excess mortality, a detailed evaluation is difficult for the following reasons: if a mortality study is based on a long-term follow-up of a group of patients attending a diabetic clinic, it is necessary to ensure, if possible, that the patients are representative of the diabetic population at large. Furthermore, bias will possibly be introduced because patients may be lost to follow-up. An alternative basis for prognosis evaluation is population-based samples of death certificates which inform about the relative importance of diabetes as a determinant of death. However, the value of such a study is inherently dependent upon the validity and reliability of the information on the certificates.

One approach that circumvents these problems is to perform a longitudinal mortality study on a well-defined, population-based patient group in which all individuals can be followed. The present study comprises a 7-year follow-up of a prevalent population of insulintreated diabetic patients $[3,4]$.

\section{Subjects and methods}

\section{The patient group}

Using insulin prescriptions from a 5-month period, the prevalent population of insulin-treated diabetic patients in the Funen County, Denmark, as of 1 July 1973, was ascertained as described earlier [3, 4]. The final material, comprising 783 males and 716 females (Table 1), all with diabetes verified from hospital records or certificates from general practitioners, has been estimated to be more than $98 \%$ complete and representative of the total Danish population of insulin-treated diabetics [3]. For all patients, basic clinical data (age at onset [determined as age at diagnosis), history of insulin treatment, daily dosage on the prevalence date] as well as information on contact with a diabetic clinic were obtained from medical records. Personal identification number (including date of birth) and current address were recorded from the prescriptions and substantiated from the public registries.

\section{Follow-up data}

Survival status was assessed with reference to 1 July 1980 , that is 7 years after the prevalence date. This was done by a record linkage with the Funen County part of the Danish centralized person registry (which comprises data from all public registries in the region), supplemented by requests to local public registries for those individuals who 
Table 1. The size of the prevalent population of insulin-treated diabetic patients in the Funen County, Denmark as of 1 July 1973

\begin{tabular}{|c|c|c|c|c|c|c|c|c|}
\hline $\begin{array}{l}\text { Age at onset } \\
\text { (years) }\end{array}$ & $\begin{array}{l}\text { Sex } \\
\text { male/female }\end{array}$ & \multicolumn{6}{|c|}{ Age as of 1 July 1973 (years) } & Total \\
\hline$<30$ & $\begin{array}{l}\mathrm{M} \\
\mathrm{F}\end{array}$ & $\begin{array}{l}209(6) \\
147(3)\end{array}$ & $\begin{array}{l}94(16) \\
77 \quad(8)\end{array}$ & $\begin{array}{l}61(12) \\
46(7)\end{array}$ & $\begin{array}{ll}34 & (7) \\
30 & (9)\end{array}$ & $\begin{array}{l}10(6) \\
14(8)\end{array}$ & $\begin{array}{ll}5 & (3) \\
0 & (-)\end{array}$ & $\begin{array}{ll}413 & (50) \\
314 & (35)\end{array}$ \\
\hline$\geqslant 30$ & $\begin{array}{l}\mathrm{M} \\
\mathrm{F}\end{array}$ & $\begin{array}{ll}- & (-) \\
- & (-)\end{array}$ & $\begin{array}{ll}19 & (0) \\
12 & (0)\end{array}$ & $\begin{array}{ll}64 & (7) \\
38 & (2)\end{array}$ & $\begin{array}{l}88(23) \\
76(12)\end{array}$ & $\begin{array}{l}115(56) \\
128(46)\end{array}$ & $\begin{array}{r}84(68) \\
148(96)\end{array}$ & $\begin{array}{l}370(154) \\
402(156)\end{array}$ \\
\hline
\end{tabular}

In parentheses: number of deaths during the follow-up period (1 July 1973-30 June 1980)

Table 2. The deaths distributed according to age at death and duration of diabetes mellitus: the prevalent population of insulin-treated diabetic patients in the Funen County, Denmark followed during the period 1 July 1973-30 June 1980

\begin{tabular}{|c|c|c|c|c|c|c|c|c|}
\hline \multirow{2}{*}{$\begin{array}{l}\text { Duration of } \\
\text { diabetes at } \\
\text { death } \\
\text { (years) }\end{array}$} & \multirow{2}{*}{$\begin{array}{l}\text { Sex } \\
\text { male/female }\end{array}$} & \multicolumn{6}{|c|}{ Age at death (years) } & \multirow[t]{2}{*}{ Total } \\
\hline & & $0-29$ & $30-39$ & $40-49$ & $50-59$ & $60-69$ & $70+$ & \\
\hline $0-9$ & $\mathrm{~F}$ & $0(-)$ & $0(-)$ & $2(2)$ & 4 (1) & $10(8)$ & $17(15)$ & $33(26)$ \\
\hline $10-19$ & M & $2(2)$ & $6(5)$ & $3(3)$ & $13(8)$ & $20(19)$ & $30(29)$ & $74(66)$ \\
\hline $20+$ & $\mathrm{F}$ & $0(-)$ & $6(5)$ & 4 (4) & $12(11)$ & $19(19)$ & $45(36)$ & $86(75)$ \\
\hline \multirow{2}{*}{ Total } & $\mathbf{M}$ & $2(2)$ & $14(13)$ & $16(16)$ & $27(21)$ & $52(46)$ & $92(78)$ & $203(176)$ \\
\hline & $\mathrm{F}$ & $2(2)$ & $7(6)$ & $7(7)$ & $17(13)$ & $46(41)$ & $111(89)$ & $190(158)$ \\
\hline
\end{tabular}

In parentheses: diabetes notified on death certificate. Two deaths excluded (see text)

appeared to have moved out of the county. For deceased individuals and emigrants the date of death or emigration, respectively, was obtained from the registries as described above, and copies of the death certificates were collected at the National Registry for Deaths, kept at the Danish National Board of Health.

\section{Statistical analysis}

The statistical analysis was based on Cox's regression model for survival data $[5,6]$ in which the hazard (force, intensity) of mortality for a given patient is a product of a function of age, sex and a term describing the effect of other covariates. The general formulation is $\lambda_{z, s}(t)=\lambda_{0, s}(t) \exp \left(\beta_{1} z_{1}+\ldots+\beta_{k} z_{k}\right)$,

where $t$ denotes actual age, $s$ sex and $z_{1}, \ldots, z_{k}$ values of other covariates. For each $s$ the hazard $\lambda_{0, s}(t)$ is an unspecified function of age. The regression coefficients $\beta_{1}, \ldots, \beta_{\mathrm{k}}$ describe the influence of the corresponding covariates $z_{1}, \ldots, z_{k}$. The set of covariates of a given individ$\mathrm{ual}$ is denoted $\mathrm{z}$.

All individuals were included in the risk set from age on 1 July 1973 until death or censoring (i.e. being alive on 1 July 1980 or on date of emigration)

The values of regression coefficients $(\beta)$ and their standard errors as well as the integrated hazards $A_{0, s}(\mathrm{t})=\int_{0}^{t} \lambda_{0, s}(\mathrm{u})$ du were estimated. The test of the hypothesis that some $\hat{\beta}$-value is 0 was based on the statistic $\hat{\beta} / \sqrt{\operatorname{var} r(\hat{\beta})}$ which is approximately normally distributed [6]. From the estimated integrated hazards survival rates, specified for age intervals and values of covariates, were estimated according to standard actuarian statistical methods. One basic assumptions underlying the regression model is that the logarithm of the hazard is linear; this was checked by introducing a square term and testing that the corresponding regression coefficient was 0 .

\section{Results}

\section{Overview}

Of the 1499 patients, one male and one female emigrated at age 33 and 9 years, respectively; these persons have been considered under observation until date of emigration. Among the remaining patients, 204 males and 191 females died during the follow-up period (Table 1). In all cases except two (one male who died at age 62 after 18 years of diabetes and one female who died at age 50 after 37 years of diabetes) copies of death certificates were obtained. A survey of the deaths (excluding the two for which the death certificate could not be found) is given in Table 2 showing the distribution according to age and disease duration at death; in addition the number of death certificates on which diabetes was notified is shown. For males and females combined diabetes was notified on the death certificate in 334 cases $(85 \%)$, but with variation as to diabetes duration; thus the proportion of diabetes-positive certificates among deaths after $0-9,10-19$ and 20 or more years of diabetes were $71 \%, 85 \%$ and $90 \%$, respectively.

Of the 393 deaths, $131(33.3 \%)$ took place outside hospital; these latter deaths were similar in distribution with respect to sex, age and duration of diabetes to deaths in hospital. The proportion of diabetes-positive 
Table 3. Regression analysis of mortality, expressed as hazard $(\lambda)$, of insulin-treated diabetes: the prevalent population of insulin-treated diabetic patients in the Funen County, Denmark, followed during the period 1 July 1973-30 June 1980

\begin{tabular}{|c|c|c|}
\hline Specification of covariates & $\begin{array}{l}\text { Estimate of re- } \\
\text { gression coeffi- } \\
\text { cients } \beta \text { (with } 1 \\
\text { standard error) }\end{array}$ & $\begin{array}{l}p \text {-value of } \\
\text { test of } \hat{\beta}=0 \\
\text { (two-sided) }\end{array}$ \\
\hline$z_{1}:$ Age at onset (years) ${ }^{a}$ & $\begin{array}{r}\hat{\beta}_{1}=-0.014 \\
(0.005)\end{array}$ & 0.002 \\
\hline$z_{1}:$ Age at onset (years) & $\begin{array}{r}\hat{\beta}_{1}=-0.015 \\
(0.005)\end{array}$ & 0.002 \\
\hline $\mathrm{z}_{2}:$ History of insulin treatment ${ }^{\mathrm{a}, \mathrm{b}}$ & $\begin{array}{l}\hat{\beta}_{2}=0.08 \\
(0.13)\end{array}$ & 0.53 \\
\hline $\begin{aligned} z_{2}=1: & \text { continous insulin treat- } \\
& \text { ment, initiated at latest } \\
& \text { one year after diagnosis } \\
z_{2}=2: & \text { other history }\end{aligned}$ & & \\
\hline$z_{1}:$ Age at onset (years) ${ }^{a}$ & $\begin{array}{r}\hat{\beta}_{1}=-0.013 \\
(0.005)\end{array}$ & 0.004 \\
\hline $\begin{array}{l}\mathrm{z}_{2}: \text { Contact with diabetes } \text { clinic }^{\mathrm{a}} \\
\mathrm{z}_{2}=1 \text { : yes. } \quad \mathrm{z}_{2}=2 \text { : no. }\end{array}$ & $\begin{array}{r}\hat{\beta}_{2}=-0.08 \\
(0.13)\end{array}$ & 0.53 \\
\hline$z_{1}$ : Age at onset (years) ${ }^{\mathrm{a}}$ & $\begin{array}{r}\hat{\beta}_{1}=-0.014 \\
(0.005)\end{array}$ & 0.002 \\
\hline $\mathrm{z}_{2}:$ Calendar time (years) ${ }^{\mathrm{a}}$ & $\begin{array}{r}\hat{\beta}_{2}=-0.042 \\
(0.026)\end{array}$ & 0.10 \\
\hline $\mathrm{z}_{1}$ : Age at onset (years) & $\begin{array}{r}\hat{\beta}_{1}=-0.012 \\
(0.004)\end{array}$ & 0.002 \\
\hline $\begin{aligned} z_{2}: & \operatorname{Sex}\left(z_{2}=1: \text { female. }\right. \\
& \left.z_{2}=2: \text { male }\right)\end{aligned}$ & 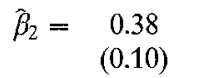 & 0.008 \\
\hline
\end{tabular}

a The analysis was performed with stratification of sex. ${ }^{b}$ In this subset of the analysis only 1290 patients with known history of insulin treatment were included.

General formulation: $\lambda_{\mathrm{zs}}(\mathrm{t})=\lambda_{0, s}(\mathrm{t}) \exp \left(\beta_{1} \mathrm{z}_{1}+, \ldots, \beta_{\mathrm{k}} \mathrm{z}_{\mathrm{k}}\right)$ (see text)

death certificates among deaths outside hospital was 124 out of $131(95 \%)$.

\section{Regression analysis}

The results of the regression analysis are given in Table 3. Of the variables included only age at onset appeared to influence the mortality significantly; the negative sign of the regression coefficient implies that, with levels of other determinants being equal, low age at onset appeared to be associated with high mortality. As the follow-up period had a length of 7 years it has been possible to include the calendar time as variable in order to evaluate secular trends in mortality; the negative sign and the magnitude of the corresponding regression coefficient imply that the hazard of mortality decreased by roughly $4 \%$ annually during the follow-up period (the levels of all other determinants kept constant), but the $p$ value of $10 \%$ (two-sided) indicated non-significance. The analyses described above were performed with allowance for different sex-specific underlying

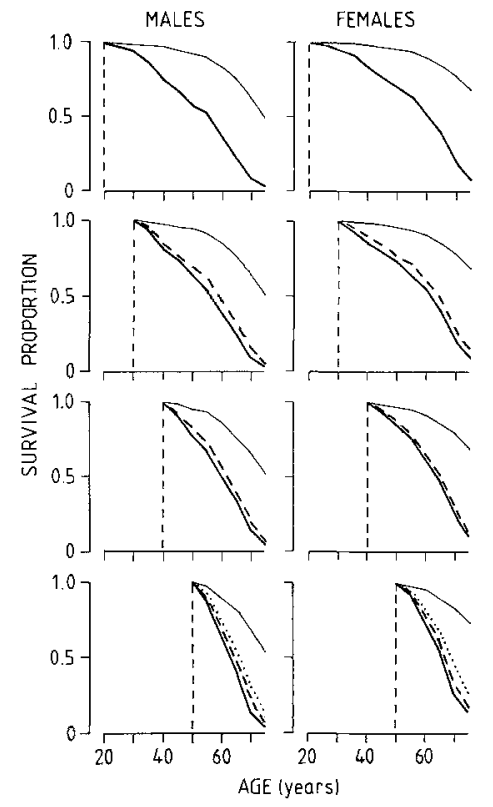

Fig. 1. Estimated survival curves for insulin-treated diabetic patients according to sex, selected levels of current age and age at onset. Current age: broken vertical line. Age at onset: -10 years; --30 years; $\cdots .50$ years

hazards. As it appeared that the estimated integrated hazards were almost proportional for the two sexes, the final regression model was based on the assumption of proportionality, i.e. sex was included as covariate together with age at onset and $\lambda_{0, \mathrm{~s}}$ was assumed independent of sex. The regression coefficients (with one standard error in parantheses) were $-0.012(0.004)$ for age at onset and $0.38(0.10)$ for sex, both highly significant; the coefficient for sex implies a higher mortality for males than for females.

\section{Predicted survival curves}

Using the final regression model described above, survival curves were drawn for each sex according to selected levels of current age (20,30, 40 and 50 years) and selected levels of age at onset (10,30 and 50 years) (Fig. 1); for comparison corresponding survival curves for the general Danish population were obtained from published vital statistics [7]. For example, among male diabetic patients with current age of 20 years and age 10 years at onset, $59 \%$ will survive to age 50 years compared with $94 \%$ in the general population. The corresponding values for female patients are $70 \%$ and $96 \%$, respectively. The survival curves illustrate that male patients have higher mortality than comparable females and that low age at onset is associated with high mortality.

\section{Causes of death}

The deaths were classified according to the recommendations of WHO [8], and Table 4 shows the deaths 
Table 4. The observed and expected $d^{a}$ deaths distributed according to cause of death ${ }^{b}$ and age at death: The prevalent population of insulin-treated diabetic patients in the Funen County, Denmark followed during the period 1 July 1973-30 June 1980

\begin{tabular}{|c|c|c|c|c|c|c|c|c|c|c|c|c|c|c|c|c|c|}
\hline \multirow[t]{3}{*}{ Cause of death } & & \multicolumn{12}{|c|}{ Age at death (years) } & \multirow{2}{*}{\multicolumn{2}{|c|}{ Total }} & \multirow{3}{*}{$\begin{array}{l}\text { Total } \\
\text { (male }+ \\
\text { female) }\end{array}$} & \multirow{3}{*}{$\begin{array}{l}\text { Ob- } \\
\text { served/ } \\
\text { expected }\end{array}$} \\
\hline & & \multicolumn{2}{|l|}{$1-29^{c}$} & \multicolumn{2}{|l|}{$30-39$} & \multicolumn{2}{|l|}{$40-49$} & \multicolumn{2}{|l|}{$50-59$} & \multicolumn{2}{|l|}{$60-69$} & \multicolumn{2}{|l|}{$70+$} & & & & \\
\hline & & Male & Female & Male & Female & Male & Female & Male & Female & Male & Female & Male & Female & Male & Female & & \\
\hline Diabetic nephropathy & Observed & 1 & 0 & 6 & 2 & 3 & 1 & 3 & 1 & 2 & 5 & 1 & 3 & 16 & 12 & 28 & \\
\hline Diabetes, other causes & Observed & 0 & 0 & 0 & 3 & 0 & 1 & 1 & 5 & 3 & 6 & 4 & 5 & 8 & 20 & 28 & \\
\hline Diabetes, total & $\begin{array}{l}\text { Observed } \\
\text { Expected }\end{array}$ & $\begin{array}{l}1 \\
0.01\end{array}$ & $\begin{array}{l}0 \\
0.01\end{array}$ & $\begin{array}{l}6 \\
0.02\end{array}$ & $\begin{array}{l}5 \\
0.01\end{array}$ & $\begin{array}{l}3 \\
0.05\end{array}$ & $\begin{array}{l}2 \\
0.02\end{array}$ & $\begin{array}{l}4 \\
0.09\end{array}$ & $\begin{array}{l}6 \\
0.03\end{array}$ & $\begin{array}{l}5 \\
0.16\end{array}$ & $\begin{array}{l}11 \\
0.17\end{array}$ & $\begin{array}{l}5 \\
0.18\end{array}$ & $\begin{array}{l}8 \\
0.48\end{array}$ & $\begin{array}{l}24 \\
0.51\end{array}$ & $\begin{array}{l}32 \\
0.72\end{array}$ & $\begin{array}{lc}56 & (14)^{\mathrm{d}} \\
1.23 \quad(I)\end{array}$ & 45.5 \\
\hline Cardiovascular diseases & $\begin{array}{l}\text { Observed } \\
\text { Expected }\end{array}$ & $\begin{array}{l}1 \\
0.03\end{array}$ & $\begin{array}{l}2 \\
0.01\end{array}$ & $\begin{array}{l}4 \\
0.12\end{array}$ & $\begin{array}{l}1 \\
0.04\end{array}$ & $\begin{array}{l}9 \\
1.00\end{array}$ & $\begin{array}{l}1 \\
0.20\end{array}$ & $\begin{array}{l}18 \\
3.15\end{array}$ & $\begin{array}{l}8 \\
0.78\end{array}$ & $\begin{array}{l}38 \\
7.52\end{array}$ & $\begin{array}{l}24 \\
3.39\end{array}$ & $\begin{array}{l}62 \\
13.19\end{array}$ & $\begin{array}{l}71 \\
19.24\end{array}$ & $\begin{array}{l}132 \\
25.01\end{array}$ & $\begin{array}{l}107 \\
23.66\end{array}$ & $\begin{array}{ll}239 & (6 I) \\
48.67 & (45)\end{array}$ & 4.9 \\
\hline Malignant diseases & $\begin{array}{l}\text { Observed } \\
\text { Expected }\end{array}$ & $\begin{array}{l}0 \\
0.11\end{array}$ & $\begin{array}{l}0 \\
0.05\end{array}$ & $\begin{array}{l}0 \\
0.15\end{array}$ & $\begin{array}{l}0 \\
0.16\end{array}$ & $\begin{array}{l}1 \\
0.09\end{array}$ & $\begin{array}{l}1 \\
0.67\end{array}$ & $\begin{array}{l}2 \\
2.24\end{array}$ & $\begin{array}{l}2 \\
2.06\end{array}$ & $\begin{array}{l}6 \\
5.12\end{array}$ & $\begin{array}{l}8 \\
4.14\end{array}$ & $\begin{array}{l}13 \\
5.71\end{array}$ & $\begin{array}{l}6 \\
6.98\end{array}$ & $\begin{array}{l}22 \\
13.42\end{array}$ & $\begin{array}{l}17 \\
14.06\end{array}$ & $\begin{array}{ll}39 & (10) \\
27.48 & (25)\end{array}$ & 1.4 \\
\hline Other natural causes & $\begin{array}{l}\text { Observed } \\
\text { Expected }\end{array}$ & $\begin{array}{l}0 \\
0.18\end{array}$ & $\begin{array}{l}0 \\
0.12\end{array}$ & $\begin{array}{l}2 \\
0.17\end{array}$ & $\begin{array}{l}0 \\
0.08\end{array}$ & $\begin{array}{l}1 \\
1.24\end{array}$ & $\begin{array}{l}3 \\
0.28\end{array}$ & $\begin{array}{l}2 \\
1.46\end{array}$ & $\begin{array}{l}1 \\
0.82\end{array}$ & $\begin{array}{l}2 \\
3.28\end{array}$ & $\begin{array}{l}3 \\
2.03\end{array}$ & $\begin{array}{l}9 \\
6.23\end{array}$ & $\begin{array}{l}21 \\
9.21\end{array}$ & $\begin{array}{l}16 \\
12.56\end{array}$ & $\begin{array}{l}28 \\
12.54\end{array}$ & $\begin{array}{ll}44 & (11) \\
25.10 & (23)\end{array}$ & 1.8 \\
\hline Non-natural causes & $\begin{array}{l}\text { Observed } \\
\text { Expected }\end{array}$ & $\begin{array}{l}0 \\
0.65\end{array}$ & $\begin{array}{l}0 \\
0.16\end{array}$ & $\begin{array}{l}2 \\
0.47\end{array}$ & $\begin{array}{l}1 \\
0.16\end{array}$ & $\begin{array}{l}2 \\
0.65\end{array}$ & $\begin{array}{l}0 \\
0.23\end{array}$ & $\begin{array}{l}1 \\
0.62\end{array}$ & $\begin{array}{l}0 \\
0.35\end{array}$ & $\begin{array}{l}1 \\
0.70\end{array}$ & $\begin{array}{l}0 \\
0.51\end{array}$ & $\begin{array}{l}3 \\
0.75\end{array}$ & $\begin{array}{l}5 \\
1.26\end{array}$ & $\begin{array}{l}9 \\
3.84\end{array}$ & $\begin{array}{l}6 \\
2.67\end{array}$ & $\begin{array}{ll}15 & (4) \\
6.51 & (6)\end{array}$ & 2.3 \\
\hline Total & $\begin{array}{l}\text { Observed } \\
\text { Expected }\end{array}$ & $\begin{array}{l}2 \\
0.98\end{array}$ & $\begin{array}{l}2 \\
0.35\end{array}$ & $\begin{array}{l}14 \\
0.93\end{array}$ & $\begin{array}{l}7 \\
0.45\end{array}$ & $\begin{array}{l}16 \\
3.03\end{array}$ & $\begin{array}{l}7 \\
1.40\end{array}$ & $\begin{array}{l}27 \\
7.56\end{array}$ & $\begin{array}{l}17 \\
4.04\end{array}$ & $\begin{array}{l}52 \\
16.78\end{array}$ & $\begin{array}{l}46 \\
10.24\end{array}$ & $\begin{array}{l}92 \\
26.06\end{array}$ & $\begin{array}{l}111 \\
37.17\end{array}$ & $\begin{array}{l}203 \\
55.34\end{array}$ & $\begin{array}{l}190 \\
53.65\end{array}$ & $\begin{array}{l}393 \quad(100) \\
108.99(100)\end{array}$ & 3.6 \\
\hline
\end{tabular}

Expected values calculated on the basis of data from the Danish National Board of Health [9].

h Cause of death classified according to the recommendations of WHO [8]. Two deaths excluded (see text).

Infant deaths excluded from the calculation of the number of expected deaths.

d Percentage proportion of total in parentheses

grouped by sex and age at death. Expected numbers were calculated from mortality statistics [9]. Diabetes was the cause of death in 56 cases $(14 \%)$, but in half of these cases diabetic renal failure was specifically stated as the cause of death.

For both sexes a higher than expected number of deaths was found in all categories of causes, the observed/expected ratio being highest for diabetes itself and cardiovascular diseases. In total (both sexes and all categories combined) the observed/expected ratio (given the actual age and sex structure) was 3.6. In the total column (males and females combined) the cause-specified absolute numbers of observed and expected deaths has been compared with the respective relative distributions. Although cancer deaths and deaths due to other natural causes in absolute numbers exceeded expected values, there were proportionately fewer deaths than expected in both of these groups; the discrepancy arises from the overwhelmingly high excess mortality due to diabetes itself and cardiovascular diseases.

\section{Discussion}

Our study has confirmed previous findings [10-14] that diabetes is associated with an excess mortality; thus, the overall observed/expected ratio of the number of deaths during the 7 years follow-up period in the present study was 3.6. Among the variables included in our analysis only age at onset and sex were significant determinants of mortality: the longer disease duration, the higher death risk, given sex and actual age.

As in previous studies [10,13], we found a pronounced excess mortality due to cardiovascular deaths, but we also found an excess mortality in all other categories, even the malignant diseases. However, these findings should only be considered as indications for further and more detailed studies of mortality because of the well-known errors associated with death certificates [2]. Our study also demonstrates that there is a considerable proportion of death certificates of deceased insulin-treated diabetic patients without diabetes mentioned at all on the certificates. Thus we conclude, as did Bale and Entmacher [11], that from an epidemiological point of view a study solely based on death certificates leads to an underestimate of the mortality in diabetes.

In contrast to a large recent Danish study [12], we could not demonstrate a better survival for patients attending a diabetic outpatient clinic. However, interpreting the data is difficult because it was impossible for us to assess the attendance pattern for each patient during the total disease course. Also attending a diabetic clinic may vary from mere control of urinary and blood glucose levels without personal contact with a physician to regular interviews combined with clinical and biochemical examinations. Finally, the factors determining which patients attended an outpatient clinic are unknown; these patients are probably selected and not directly comparable with those not attending a clinic on a regular basis.

In conclusion, we recommend that further longitudinal studies, evaluating the disease course of a population-based patient group should be performed by means of standardized medical records and clinical examinations. This will provide important additional information and, hopefully, explanation of the excess mortality from diabetes and its potential reducibility.

Acknowledgements. The authors are indebted to N. Keiding, Copenhagen for valuable discussions and criticism. Financial support was given by the Danish Medical Research Council (grant no. 12-1035) to 
A.G.Part of this study was performed during P.H.'s study visit to Stanford University with financial support from the Danish Natural Science Research Council.

\section{References}

1. Tunbridge WMG (1981) Factors contributing to deaths of diabetics under fifty years of age. Lancet $2: 569-572$

2. Fuller JH, Elford J, Goldblatt P, Adelstein AM (1983) Diabetes mortality: new light on an underestimated public health problem. Diabetologia 24: 336-341

3. Green A, Hauge M, Holm NV, Rasch LL (1981) Epidemiological studies of diabetes mellitus in Denmark. II. A prevalence study based on insulin prescriptions. Diabetologia 20:468-470

4. Green A, Hougaard P (1983) Epidemiological studies of diabetes mellitus in Denmark: 4. Clinical characteristics of insulin-treated diabetes. Diabetologia 25:231-234

5. Cox DR (1972) Regression models and life tables (with discussion). J R Stat Soc, Series B, 34: 187-220

6. Kalbfleisch ID, Prentice RL (1980) The statistical analysis of failure time data. Wiley, New York

7. Danmarks Statistik (1981) Statistiske Meddelelser 1981:1 ("Befolkningens bevægelser 1979"). Copenhagen

8. World Health Organization (1969) Manual of the international statistical classification of diseases, injuries, and causes of death. Geneva

9. Sundhedsstyrelsen (1980) Dødsårsagerne i Danmark året 1978. Copenhagen

10. Garcia MJ, McNamara PM, Gordon T, Kannell WB (1974) Morbidity and mortality in diabetics in the Framingham population. Sixteen year follow-up study. Diabetes 23: 105-111

11. Bale GS, Entmacher PS (1977) Estimated life expectancy of diabetics. Diabetes 26: $434-438$

12. Deckert T, Poulsen JE, Larsen M (1979) The prognosis of insulin dependent diabetes mellitus and the importance of supervision. Acta Med Scand (Suppl) 624: 48-53

13. Królewski AS, Czyzyk A, Janeczko D, Kopczyński J (1977) Mortality from cardiovascular diseases among diabetics. Diabetologia 13: $345-350$

14. Panzram G, Zabel-Langhennig R (1981) Prognosis of diabetes mellitus in a geographically defined population. Diabetologia 20: $587-591$

Received: 11 April 1983

and in revised form: 22 November 1983

Dr. Anders Green

University Institute of Clinical Genetics

J.B. Winsløwsvej 17

DK-5000 Odense C

Denmark 